\title{
Brown seaweed extract enhances rooting and roots growth on Passiflora actinia Hook stem cuttings ${ }^{(1)}$
}

\author{
ERIK NUNES GOMES(2)* LEANDRO MARCOLINO VIEIRA ${ }^{(3)}$; JÉSSICA DE CÁSSIA TOMASI(3), \\ MAÍRA MACIEL TOMAZZOLI(3), RENATA LÚCIA GRUNENNVALDT(3), CÍNTIA DE MORAES FAGUNDES ${ }^{(3)}$, RAFAELA \\ CRISTINA BRUNETTI MACHADO(3)
}

\begin{abstract}
Passiflora actinia Hook (common name: 'maracujá do mato') is an important medicinal species due to significant sedative and anxiolytic activities. In order to commercially exploit the plant, however, studies on propagation to improve rooting in stem cuttings are needed. The present study was designed to evaluate the effect of the brown seaweed (Ascophyllum nodosum (L.) Le Jol.) extract when applied on P. actinia stem cuttings bases. Five concentrations of the extract in distilled water were evaluated: $0 \%$ (pure distilled water), $10 \%, 20 \%, 30 \%$ and $40 \%$. The experimental design was completely randomized with 4 repetitions and 12 cuttings per experimental unit. Cuttings were evaluated 45 days from planting. Data were analyzed through polynomial regression analysis and Pearson's correlation coefficients were calculated for all the variables. On average, $51.27 \%$ rooting was achieved. Rooting percentage increased linearly according to the brown seaweed extract concentrations. When compared to the control treatment, about $10 \%$ increase in rooting was observed at the treatment with $40 \%$ seaweed extract. Leaf retention response to A. nodosum increasing concentrations was also adjusted in a positive linear model. A $15.6 \%$ increase in leaf retention was observed at the $40 \%$ seaweed concentration when compared to the control. Positive correlations were observed for leaf retention and rooting percentage and leaf retention and roots length. The immersion of $P$. actinia stem cuttings bases in A. nodosum extract at a concentration of $40 \%$ promote positive effects on rooting and facilitate the species propagation.
\end{abstract}

Keywords: Acadian ${ }^{\circledR}$, Ascophyllum nodosum (L.) Le Jol., biostimulant, maracujá-do-mato.

\section{RESUMO}

Extrato de alga marinha estimula o enraizamento e crescimento radicial em estacas caulinares de Passiflora actinia Hook

Passiflora actinia Hook (nome popular: 'maracujá-do-mato') é uma espécie medicinal relevante devido às suas propriedades sedativas e ansiolíticas. Para uma exploração comercial da planta, no entanto, são necessários estudos de propagação, especialmente visando melhorar o enraizamento em estacas caulinares. O presente estudo foi desenvolvido para avaliar o efeito do extrato da alga marinha parda (Ascophyllum nodosum (L.) Le Jol.) aplicado na base de estacas caulinares de P. actinia. Foram avaliadas cinco concentrações do extrato diluído em água destilada: $0 \%$ (água destilada pura), 10\%, 20\%,30\% e 40\%. O delineamento experimental foi o inteiramente casualizado com 4 repetições e 12 estacas por unidade amostral. As estacas foram avaliadas 45 dias após o plantio. Os dados foram analisados por meio de análise de regressão polinomial e coeficientes de correlação de Pearson foram calculados para todas as variáveis. Em média, verificou-se 51,27\% de enraizamento. A porcentagem de enraizamento aumentou linearmente de acordo com as concentrações de extrato de alga marinha. Quando comparado ao tratamento controle, observou-se aumento de $10 \%$ no enraizamento quando as estacas foram tratadas com $40 \%$ de extrato de alga marinha. A resposta de retenção foliar às concentrações de $A$. nodosum também foi ajustada em modelo linear positivo. Um aumento de 15,6\% na retenção foliar foi observado na concentração de $40 \%$ de extrato de alga quando comparado ao controle. Correlações positivas foram observadas para retenção de folhas e porcentagem de enraizamento e retenção de folhas e comprimento de raízes. A imersão das bases de estacas de P. actinia em extrato de A. nodosum em uma concentração de $40 \%$ pode promover efeitos positivos no enraizamento e facilitar a propagação desta espécie.

Palavras-chave: Acadian ${ }^{\circledR}$, Ascophyllum nodosum (L.) Le Jol., bioestimulante, maracujá $\square$ do $\square$ mato.

DOI: http://dx.doi.org/10.14295/oh.v24i3.1221

${ }^{(1)}$ Received in 30/05/2018 and accepted in 18/09/2018

${ }^{(2)}$ Rutgers, The State University of New Jersey, Department of Plant Biology, New Brunswick, New Jersey, United States. *Corresponding author: e93gomes@gmail.com

${ }^{(3)}$ Universidade Federal do Paraná, Departamento de Fitotecnia e Fitossanitarismo, Setor de Ciências Agrárias, Curitiba, Paraná, Brasil. 


\section{INTRODUCTION}

Passifloraceae family comprises about 19 genera and 530 species dispersed in tropical and subtropical regions, especially in America and Africa. The genus Passiflora is the most representative of the family, with approximately 400 species (BERNACCI, 2003). Passiflora species are widely used in traditional medicine, mainly as sedatives, anxiolytics and anticonvulsants (DHAWAN et al., 2004). Studies report the presence of diverse phytochemical compounds in Passiflora, such as flavonoids, phenolic acids, coumarins, phytosterols, cyanogenic heterosides, maltol and alkaloids (ZUANAZZI and MONTANHA, 2004). Among the bioactive compounds conferring the calming effects attributed to the genus, the C-glycosyl flavonoids (SANTOS et al., 2016), chrysin (ZANOLI et al., 2000) and maltol (AOYAGI et al., 1974) are some of the most important.

Passiflora actinia Hook (common name: 'maracujá-domato') is a Brazilian native species widely distributed in Southern states (SANTOS et al., 2016). This species stands out due to significant sedative and anxiolytic activities, mainly related to the leaves major compound isovitexin, which acts on benzodiazepine gamma-aminobutyric acid-A receptors (SANTOS et al., 2016; LOLLI et al., 2007). In addition to the secondary metabolites of medicinal interest, the species is extensively appreciated for human and animal feeding (LIMA et al., 2007) and also widely recognized for its use as a rootstock for commercial passionfruit farming, due to its tolerance to low temperatures (PIRES et al., 2009).

The study of suitable methods for propagation is one of the primordial aspects for the agronomic exploration of vegetal species (NUNES GOMES and KRINSKI, 2016 b). Vegetative propagation by stem cuttings is one of the most widely used propagation methods in commercial production of various medicinal, fruit and ornamental crops. Among the advantages of this type of propagation, the reproduction of stock plants characteristics, uniformity of populations and operational ease stand out (HARTMAN et al., 2011). Several factors can influence vegetative reproduction success. Types of cuttings, substrates, environment humidity, hormonal balance and stock plants health, physiological conditions, and genetic characteristics are some of the main aspects pointed out as influent for stem cuttings adventitious rooting (ZUFFELLATO-RIBAS and RODRIGUES, 2001; NUNES GOMES and KRINSKI, 2016a; BISCHOFF et al., 2017; PIGATTO et al., 2018).

In addition, exogenously applied plant regulators may have positive effects on stem cuttings rooting. In a previous study on $P$. actinia vegetative propagation, the use of ethanol or indolebutyric acid (IBA) did not promote increasing in neither rooting nor roots development (KOCH et al., 2004). In this context, the study of different plant growth regulators with auxinlike effects can provide important tools to improve this species propagation. Some biostimulants are reported to have these effects, promoting rooting and roots growth in several plant species, and represent a growing tendency for use in sustainable agriculture (NARDI et al., 2016).
The brown seaweed Ascophyllum nodosum (L.) Le Jol. extract is classified as a plant growth regulator and its effects on plant growth and development vary with the extract concentration, mode of application and plant species (CRAIGIE, 2011). In terms of composition, the extract of brown seaweed is a natural source of macro and micronutrients (N, P, K, Ca, Mg, S, B, Fe, Mn, Cu and Zn), amino acids (alanine, aspartic and glutamic acid, glycine, isoleucine, leucine, lysine, methionine, phenylalanine, proline, tyrosine, tryptophan and valine), cytokinins, auxins, and abscisic acid (KOYAMA et al., 2012). Some of these components, mainly auxins and tryptophan (auxinprecursor) and micronutrients like $\mathrm{B}$ and $\mathrm{Zn}$, are largely recognized as important tools to improve adventitious rhizogenesis in stem cuttings (ZUFFELLATO-RIBAS and RODRIGUES, 2001; TAIZ and ZEIGER, 2013).

Considering this context, the present study was conducted to evaluate the effects of treating Passiflora actinia stem cuttings bases with different concentrations of the brown seaweed extract.

\section{MATERIAL AND METHODS}

Passiflora actinia plant material (branches with leaves) was collected during morning period on September 18, 2016 in Curitiba, state of Parana, Brazil (25²4'53'S, $49^{\circ} 18^{\prime} 12^{\prime \prime} \mathrm{W}, 934 \mathrm{~m}$ altitude). The region climate is classified as $\mathrm{Cfb}$, characterized by mild summers, cold and dry winter, rains evenly distributed throughout the year and frequent occurrence of frosts, according to the Köppen classification.

The plant material was moistened and carefully disposed in black plastic bags to be transported to the greenhouse where the stem cuttings were made. Branches with $2.3 \pm 0.3$ $\mathrm{mm}$ diameter were selected to prepare cuttings $10 \mathrm{~cm}$ long, with a straight cut at the apex and a bevel (diagonal) cut at the base. One leaf reduced to half of its original area was kept on the apex of each cutting (Figure 1A and 1C). Subsequently, the propagules underwent phytosanitary treatment in solution with $0.5 \%$ sodium hypochlorite during 10 minutes and then were washed in running water for 5 minutes.

After sanitary treatment, stem cuttings had their bases immersed for 2 minutes in solutions of brown seaweed extract diluted in distilled water at the following concentrations: $0 \%, 10 \%, 20 \%, 30 \%$ and $40 \%$ (e.g.: $40 \%$ solution $=0.4 \mathrm{~mL}$ seaweed extract diluted in $0.6 \mathrm{~mL}$ distilled water). The experimental design was completely randomized, with 5 treatments, 4 replications and 12 cuttings per experimental unit, totaling 240 stem cuttings. The extract used in this experiment was a commercial concentrate water-soluble liquid extract, manufactured by Acadian Seaplants ${ }^{\circledR}$ from the brown algae Ascophyllum nodosum (L.) Le Jol.

Following treatments, stem cuttings were planted in $120 \mathrm{~cm}^{3}$ polypropylene containers filled with previously moistened commercial substrate Tropstrato HT $^{\circledR}$ (Vida Verde-Tecnologia em Substratos ${ }^{\mathrm{TM}}$, Brazil). After planting, cuttings were kept in a greenhouse with intermittent misting until evaluation. Greenhouse air relative humidity was kept 
higher than $80 \%$ and the temperature ranged between 20 and $30^{\circ} \mathrm{C}$ during the period of the experiment.

After 45 days from planting, plants were evaluated regarding the following variables: rooting percentage (cuttings with roots longer than $0.1 \mathrm{~cm}$ ), average number of roots per cutting, average length of roots per cutting $(\mathrm{cm})$, calli formation percentage (cuttings with undifferentiated mass of cells at the base, as seen in figures 1B and 1D), leaf retention (cuttings that kept the original apical leaf) and, ultimately, survival percentage.
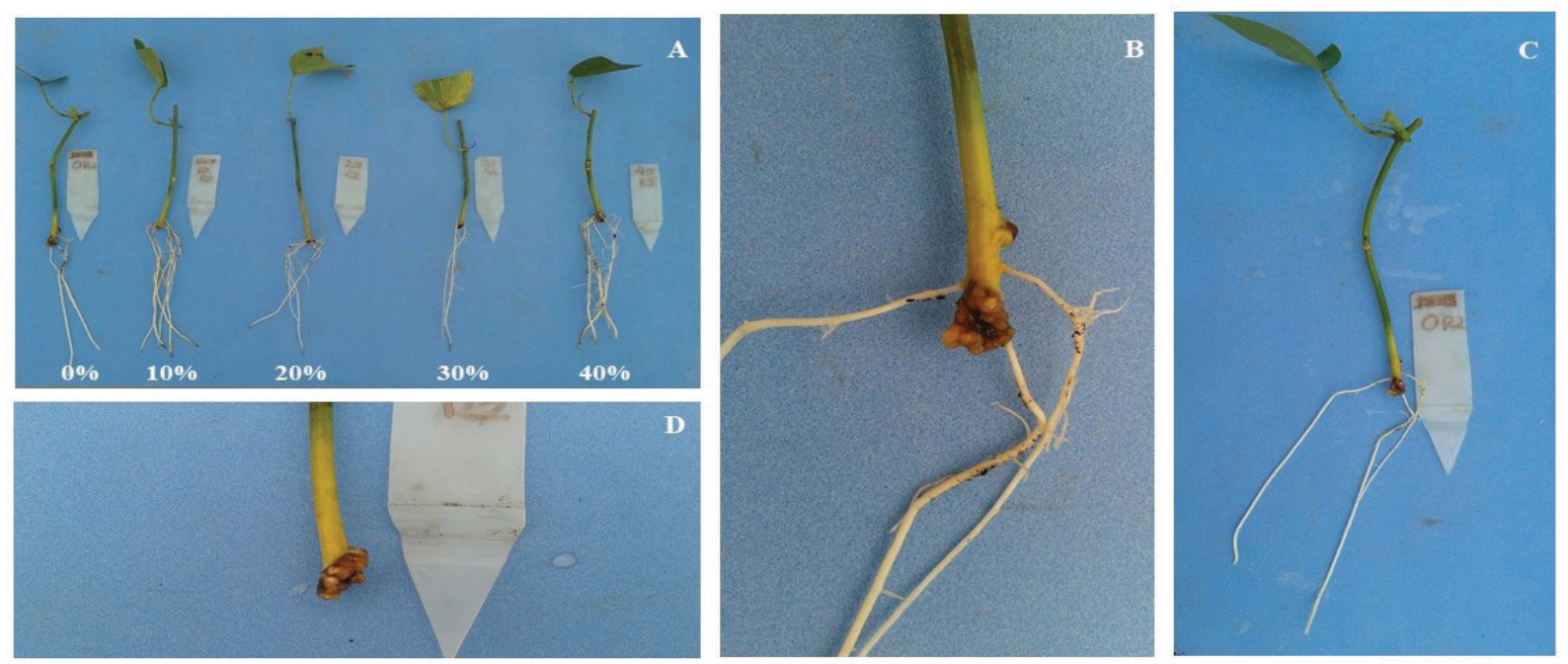

Figure 1. Passiflora actinia Hook stem cuttings after 45 days from planting. A: general overview of the effects of different concentrations of brown seaweed extracts. B: calli and roots formation in one stem cutting, evidencing that adventitoious roots did not differentiate from calli. C: Rooted stem cutting evidencing the leaf retention. D. Stem cuttings with calli formation and no rooting.

Treatments variances were evaluated regarding homogeneity by the Bartlett test at 5\% probability and, when homogeneous, data were submitted to polynomial regression analysis (5\% and $1 \%$ probability). Assistat 7.7 (SILVA and AZEVEDO, 2016) statistical software was used to perform these analyses. Pearson's correlation coefficients were calculated for all the variables using $\mathrm{R}$ software (R CORE TEAM 2016).

\section{RESULTS AND DISCUSSION}

According to variance analysis, there was a significant dose-dependent effect for all analyzed variables in Passiflora actinia Hook stem cuttings treated with the brown seaweed extract (Figure 2). Products derived from marine algae represent a relatively recent technology in Brazil and are a potential alternative for agronomic applications, mainly by the promotion of plant growth and development (DURAND et al., 2003).

According to the scientific literature, P. actinia stem cuttings root easily, achieving rooting rates of at least $40 \%$ without exogenously applied plant growth regulators (CHAVES et al., 2004; KOCH et al., 2004; ALBUQUERQUE JUNIOR et al., 2013). The present study corroborates these findings, with an average $51.27 \%$ rooting percentage (Figures $1 \mathrm{~A}$ and $2 \mathrm{~A}$ ). Despite the good performance in the control treatment, rooting percentage increased linearly according to the brown seaweed extract concentrations. When compared to the control treatment, about $10 \%$ increase in rooting was observed at the treatment with $40 \%$ seaweed extract (Figure 2A). 

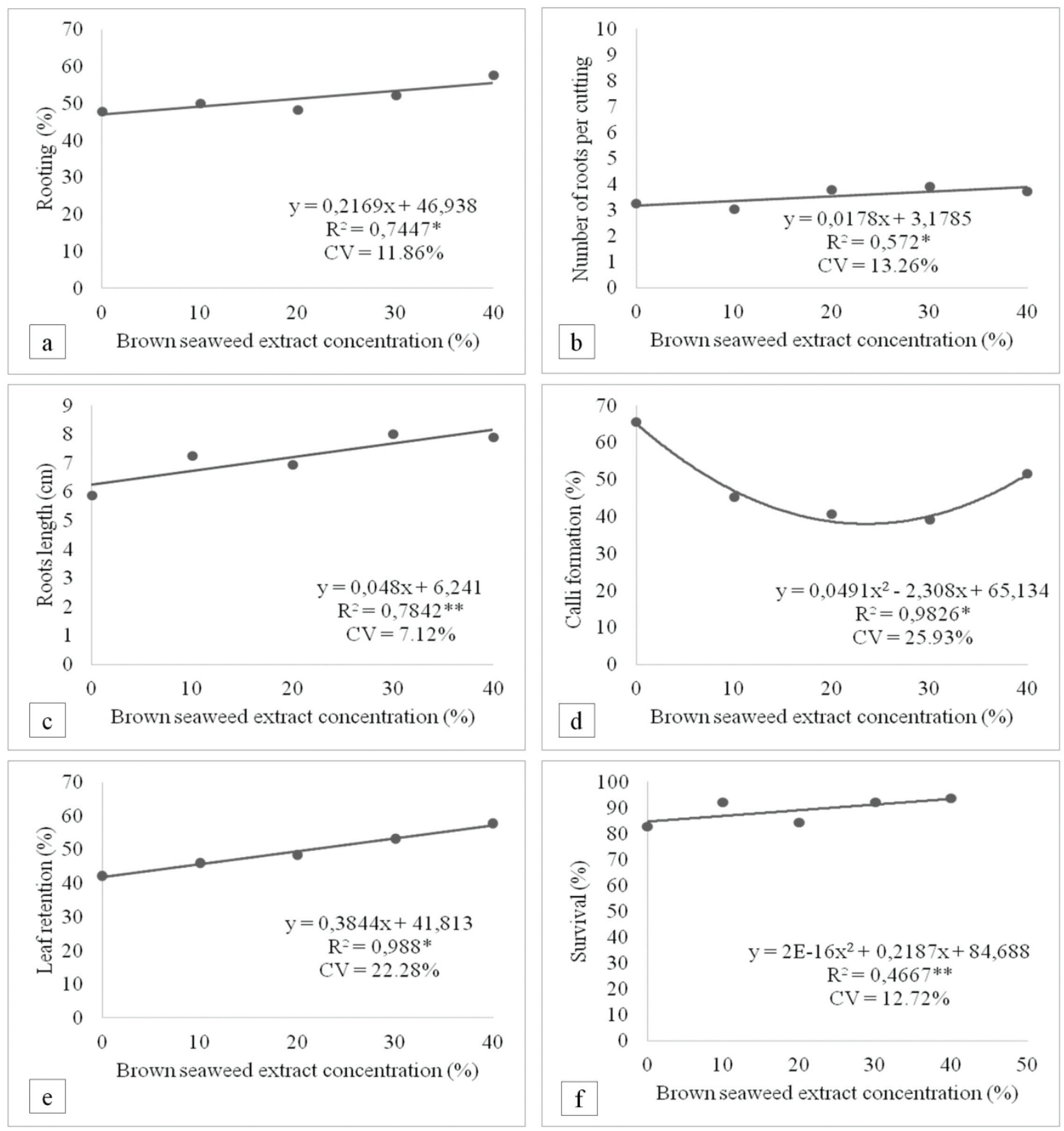

Figure 2. Polynomial regression analysis and respective equations, coefficients of determination $\left(\mathrm{R}^{2}\right)$ and coefficients of variation (CV) for the variables rooting percentage (a), number of roots per cutting (b), roots length (c), calli formation (d), leaf retention (e) and survival (f) in Passiflora actinia Hook stem cuttings treated with increasing concentrations of the brown seaweed extract. *significant at $5 \%$ probability. ** significant at $1 \%$ probability.

The same linear responses, according polynomial regression analysis, were verified for average roots length and number of roots per cutting (Figures $2 \mathrm{~B}$ and 2C, respectively). The positive effects of Ascophyllum nodosum extracts in stem cuttings rooting and roots growth can be primarily attributed to the presence of auxins, since these extracts are known to contain considerable amounts of indole-3-acetic acid (SANDERSON et al., 1987). It is a well-known fact that exogenously applied auxins act on the activation of vascular cambial cells, promoting adventitious roots emission and growth in stem cuttings (HARTMANN et al., 2011).
In addition to the exogenous auxin source, according to the data reviewed by Koyama et al. (2012), Ascophyllum nodosum extracts have significant amounts of amino acids such as aspartic and glutamic acids, glycine, tyrosine, and tryptophan. These amino acids have been reported to enhance rooting and roots number in plants species when applied in culture media and/or are correlated to better rooting performance in stem cuttings (ORLIKOWSKA et al., 1992; DUTRA et al., 2002).

Another important component of brown seaweed extract are macro and micronutrients such as $\mathrm{B}$ and $\mathrm{Zn}$ (KOYAMA et al., 2012), two of the most used mineral 
nutrients to improve rooting in stem cuttings. Zinc can enhance rooting because it is involved in the biosynthesis of tryptophan, an auxin precursor (SCHWAMBACH et al., 2005). Boron, in turn, plays an important role in cell elongation and is considered a rooting cofactor, since it acts synergistically with endogenous auxin, facilitating its transport through the cell membranes (SANTOS et al., 2010; TAIZ and ZEIGER, 2013). These components taken together can explain the better performance for rooting and roots growth in P. actinia stem cuttings and also highlight the possibilities for using these extracts as alternative plant growth regulators.

Regarding calli formation, the responses to Ascophyllum nodosum extract concentrations were represented in a quadratic model, with a higher callogenesis percentage $(65 \%)$ in the control treatment (Figure 2D). Despite the high rates of calli formation, it is important to mention that adventitious roots in $P$. actinia did not differentiated from calli, it is, the species underwent direct rhizogenesis. In some cuttings, both calli and roots formation were observed, with no direct correlation between both processes (Figure 1B and 1C). According to Hartmann et al. (2011) the processes of calli and adventitious roots formations are independent and their simultaneous occurrence is explained by the fact that both involve intense cell division and depend on favorable environmental conditions. The high callogenesis, percentage, in this case, can be an indicative of an adequate rooting environment.

The adequate rooting environment can also be observed by the high survival percentages, with an average $89.09 \%$ rate. Considering this variable, linear model was, among those tested, the one that presented statistical significance $(p \leq 0.05)$ (Figure 2F). However, due to the low coefficient of determination value $\left(\mathrm{R}^{2}=0.46\right)$, the model equation does not present reliability to explain the plant response to the extract, similarly to the results reported by Fragoso et al. (2017) on cherry tree stem cuttings treated with different IBA concentrations. It is possible to affirm for this variable, however, that $P$. actinia cuttings present high resistance to mortality, that the rooting environment allowed adequate conditions for cuttings survival and, ultimately, that the seaweed extract did not jeopardized plant material survival.

Leaf retention response to $A$. nodosum increasing concentrations was adjusted in a positive linear model(Figure $2 \mathrm{E})$. An increase of $15.6 \%$ was observed in leaf retention at the $40 \%$ seaweed concentration when compared to the control. The physiological response of leaf maintenance in $P$. actinia cuttings may be attributed to the presence of several natural cytokinins in $A$. nodosum extract, mainly zeatin, dihydrozeatin, isopentenyl adenine and isopentenyl adenosine (SANDERSON and JAMESON, 1986). It is a well-known fact that cytokinins coming up through the xylem to the leaves play an important role in retarding leaf yellowing, blade abscission, petiole abscission and, to a lesser extent, pod development (GARRISON et al., 1984).

The effects on leaf maintenance can also be a reasonable explanation for the positive effects of $A$. nodosum in $P$. actinia stem cuttings rooting. The studies from Albuquerque Junior et al. (2013) and Lima et al. (2007) clearly demonstrate a positive correlation between leaf maintenance and rooting in this species. On the present study a significant positive correlation was also observed for leaf retention and rooting percentage and leaf retention and roots length (Figure 3 ).
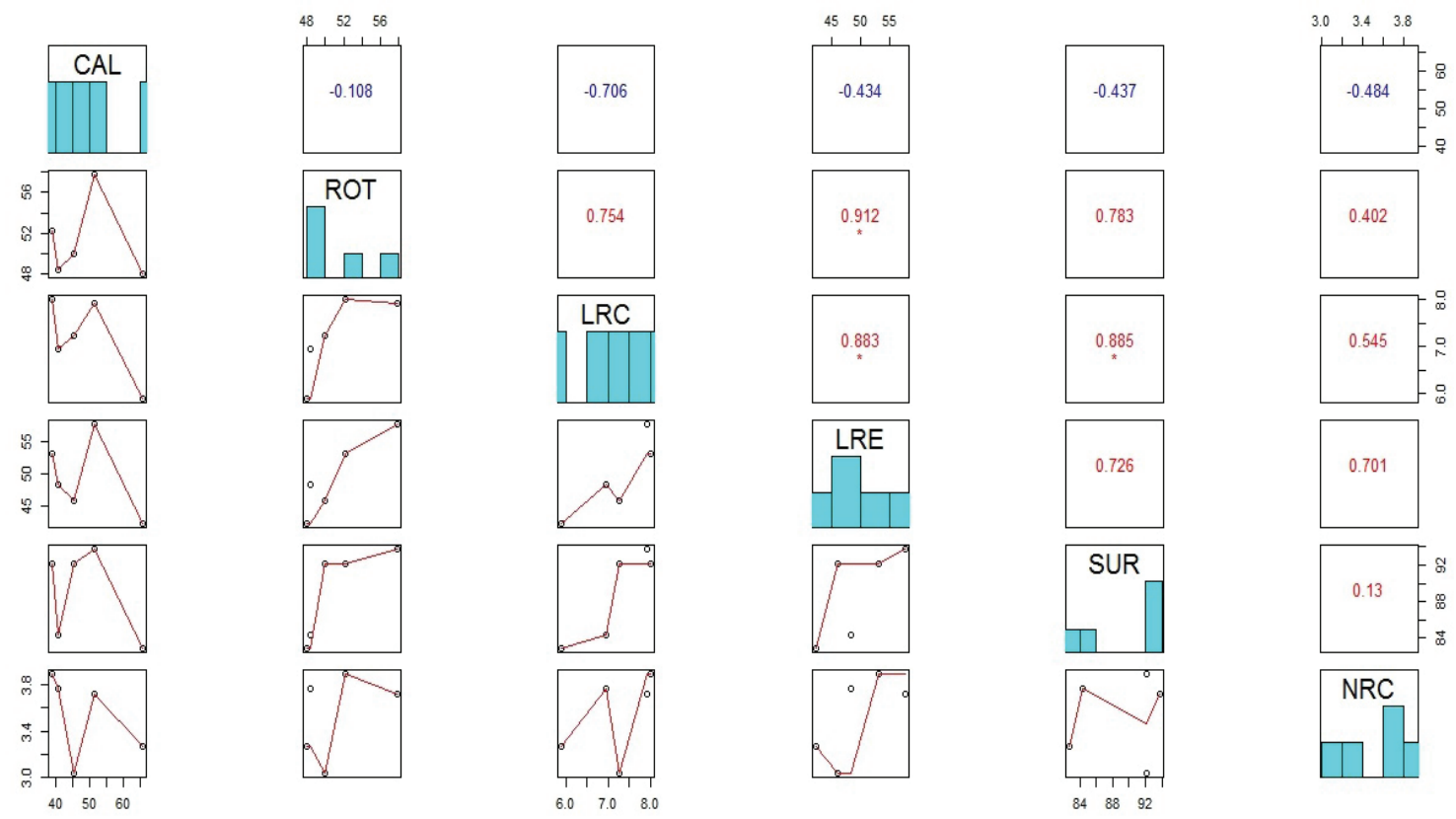

Figure 3. Pearson's correlation coefficients for ROT - rooting (\%); CAL- calli formation (\%); LRE - leaf retention (\%); SUR survival (\%); NRC- number of roots per cutting and LRC - average length of roots per cuting $(\mathrm{cm})$ in Passiflora actinia Hook stem cuttings treated with with increasing concentrations of the brown seaweed extract. *significant at 5\% probability. 
The presence of leaves is an important feature for rooting, especially when using herbaceous or semi-hardwood stem cuttings, because adventitious roots initiation and development are dependent on auxins, carbohydrates, and rooting cofactors that are supplied primarily by the leaves on this type of propagules (BONA and BIASI, 2010).

To the best of our knowledge, the present study is one of the first attempts to use Ascophyllum nodosum extract as a plant growth regulator to promote rooting in stem cuttings from medicinal species and demonstrates the versatility of this product for use in several segments of sustainable agriculture.

\section{CONCLUSIONS}

Passiflora actinia stem cuttings root easily, have elevated survival rates and present direct rhizogenesis. Immersion of stem cuttings bases for 2 minutes in a concentration of $40 \%$ Ascophyllum nodosum extract enhances rooting percentage, roots number and roots length as well as promotes a higher rate of leaf retention. Leaf retention has a positive correlation with rooting percentage and roots length in $P$. actinia stem cuttings.

\section{AUTHORS CONTRIBUTIONS}

E.N.G. D0000-0002-7999-070x: Conception of the study, implementation and final evaluation of the greenhouse study, data analysis and interpretation, drafting and critical revision of the article, final approval of the version to be published. L.M.V. (D0000-0002-9336-860x : Conception of the study, implementation and final evaluation of the greenhouse study, material and methods section writing. J.C.T. D0000-0002-4333${ }^{3521}$ : implementation and final evaluation of the greenhouse study, correlation analysis, results and discussion section writing. M.M.T. Do000-0002-9946-2701: implementation and final evaluation of the greenhouse study, correlation analysis and introduction section writing. R.L.G. (D00000002-7493-0732: implementation and final evaluation of the greenhouse study, introduction section writing. C.M.F. (D) 0000-0003-1224-6772: Final evaluation of the greenhouse study, correlation analysis, results and discussion section writing. R.C.B.M. (D)0000-0002-7793-216x: implementation and final evaluation of the greenhouse study.

\section{ACKNOWLEDGEMENTS}

The authors would like to acknowledge the Brazilian Federal Agency for Support and Evaluation of Graduate Education - CAPES for sponsorship of the research and scholarships granted. The authors also thank Federal University of Parana and the Crop Production Graduate Program for providing the plant material, seaweed extract, substrates and greenhouse structure.

\section{REFERENCES}

ALBUQUERQUE JUNIOR， C.L.; DANNER， M.A.; KANIS, L.A.; DESCHAMPS, C.; ZANETTE, F.; FARIAS, P.M.Enraizamento de estacas semilenhosas demaracujazeiro amarelo Passiflora actinia Hook. Semina: Ciências Agrárias, v.34, n.6, p.3663-3668, 2013. DOI: http://dx.doi. org/10.5433/1679-0359.2013v34n6Supl1p3663.

AOYAGI, N.; KIMURA R.; MURATA T. Studies on Passiflora incarnata dry extract. I. Isolation of maltol and pharmacological action of maltol and ethyl maltol. Chemical and Pharmaceutical Bulletin, v.22, n.5, p.10081013, 1974. DOI: https://doi.org/10.1248/cpb.22.1008

BERNACCI, L.C. Passifloraceae. In: WANDERLEY, M.G.L.; SHEPHERD, G.J.; GIULIETTI, A.M.; MELHEM, T.S. Flora fanerogâmica do Estado de São Paulo. São Paulo: RiMa, FAPESP, 2003. 247-248.

BISCHOFF, A.M.; VENDRAMIM, D.W.; NUNES GOMES, E.; ENGEL, M. L.; MAGGIONI, R.A.; ZUFFELLATO-RIBAS, K.C. Rooting of black sage cuttings according to different indole butyric acid concentrations and number of leaves. Revista de Ciências Agroveterinárias, v.16, n.1, p.41-47, 2017. DOI: http:// dx.doi.org/10.5965/223811711612017041

BONA, C.M.; BIASI, L.A. Influence of leaf retention on cutting propagation of Lavandula dentata L. Revista Ceres, v.57, n.4, p.526-529, 2010. DOI: http://dx.doi. org/10.1590/S0034-737X2010000400014

CHAVES, R.C.; JUNQUEIRA, N.T.V.; MANICA, I.; PEIXOTO, J.R.; PEREIRA, A.V.; FIALHO, J.F. Enxertia de maracujazeiro-azedo em estacas herbáceas enraizadas de espécies de passifloras nativas. Revista Brasileira de Fruticultura, v.26, n.1, p.120-123, 2004. DOI: http:// dx.doi.org/10.1590/S0100-29452004000100033

CRAIGIE, J.S. Seaweed extract stimuli in plant science and agriculture. Journal of Applied Phycology, v.23, n.3, p.371393, 2011. DOI: https://doi.org/10.1007/s10811-010-9560-4

DHAWAN, K.; DHAWAN, S.; SHARMA, A. Passiflora: a review update. Journal of Ethnopharmacology, v.94, n.1, p.1-23, 2004. DOI: https://doi.org/10.1016/j. jep.2004.02.023

DURAND, N.;BRIAND,X.;MEYER,C. The effect ofmarine bioactive substances (N PRO) and exogenous cytokinins on nitrate reductase activity in Arabidopsis thaliana. Physiologia Plantarum, v.119, n.4, p.489-493, 2003. DOI: https://doi.org/10.1046/j.1399-3054.2003.00207.x 
DUTRA, L.F.; KERSTEN, E.; FACHINELLO, J.C. Época de coleta, ácido indolbutírico e triptofano no enraizamento de estacas de pessegueiro. Scientia agrícola, v.59, n.2, p.327-333, 2002. DOI: http://dx.doi.org/10.1590/S010390162002000200019

FRAGOSO, R.O.; STUEPP, C.A.; RICKLI, H.C.; ZUFFELLATO-RIBAS, K.C.; KOEHLER, H.S. Maximum efficiency concentration of indole butyric acid in promoting the rooting of Japanese Flowering Cherry. Ciência Rural, v.47, n.1, p.1-6, 2017. DOI: http://dx.doi. org/10.1590/0103-8478cr20150894

GARRISON,F.R.;BRINKER,A.M.;NOODEN,L.D. Relative activities of xylem-supplied cytokinins in retarding soybean leaf senescence and sustaining pod development. Plant and cell physiology, v.25, n.2, p.213-224, 1984. DOI: https://doi. org/10.1093/oxfordjournals.pcp.a076704

HARTMANN, H.T.; KESTER, D.E.; DAVIES JR, F.T.; GENEVE, R.L. Plant propagation: principles e practices. Boston: Prentice Hall, 2011. 915p. 8ed.

KOCH, R.C.; BIASI, L.A.; ZANETTE, F.; POSSAMAI, J.C. Vegetative propagation of Passiflora actinia by semihardwood cuttings. Semina: Ciências Agrárias, v. 22, n. 2, p. 165-167, 2004. DOI: http://dx.doi. org/10.5433/1679-0359.2001v22n2p165

KOYAMA, R.; BETTONI, M.M.; RODER, C.; ASSIS, A.M.; ROBERTO, S.R.; MÓGOR, A.F. Extrato da alga Ascophyllum nodosum (L.) Le Jolis no desenvolvimento vegetativo e na produção do tomateiro. Revista de Ciências Agrárias, v.55, n.4, p.282-287, 2012. DOI: http://dx.doi. org/10.4322/rca.2012.067

LIMA, D.M.; ALCANTARA, G.B.; FOGAÇA, L.A.; QUOIRIN, M.; CUQUEL, F.L.; BIASI, L.A. Influência de estípulas foliáceas e do número de folhas no enraizamento de estacas semilenhosas de maracujazeiro amarelo nativo. Acta Scientiarum Agronomy, v.29, suppl.1, p. 671676, 2007. DOI: http://dx.doi.org/10.4025/actasciagron. v29i5.744

LOLLI, L.F.; SATO, C.M.; ROMANINI, C.V.; VILLARBOAS, L.B.; SANTOS, C.A.; OLIVEIRA, R.M. Possible involvement of GABA A-benzodiazepine receptor in the anxiolytic-like effect induced by Passiflora actinia extracts in mice. Journal of Ethnopharmacology, v.111, n.2, p.308-314, 2007. DOI: https://doi.org/10.1016/j. jep.2006.11.021

NARDI, S.; PIZZEGHELLO, D.; SCHIAVON, M.; ERTANI, A. Plant biostimulants: physiological responses induced by protein hydrolyzed-based products and humic substances in plant metabolism. Scientia Agricola, v.73, n.1, p.18-23, 2016. DOI: http://dx.doi.org/10.1590/01039016-2015-0006
NUNES GOMES, E.; KRINSKI, D. Propagação vegetativa de Piper amalago L. (Piperaceae) em função de tipos de estaca e substratos. Cultura Agronômica, v.25, n.2, p.199210, 2016a.

NUNES GOMES, E.; KRINSKI, D. Propagação vegetativa de Piper umbellatum L. (Piperaceae) em função de substratos e comprimentos de estacas. Scientia Agraria, v.17, n.3, p.31-37, 2016b. DOI: http://dx.doi.org/10.5380/ rsa.v17i3.49695

ORLIKOWSKA, T. Effect of amino acids on rooting of apple dwarf root stocks in vitro. Biologia plantarum, v.34, n.1-2, p.39, 1992. DOI: https://doi.org/10.1007/ BF02925788

PIGATTO, G.B.; NUNES GOMES, E.: TOMASI, J.C.; FERRIANI, A.P.; DESCHAMPS, C. Effects of indolebutyric acid, stem cutting positions and substrates on the vegetative propagation of Stevia rebaudiana Bertoni. Revista Colombiana de Ciencias Hortícolas, v.12, n.1, p.202-211, 2018. DOI: http://dx.doi.org/10.17584/ rcch.2018v12i1.6631

PIRES, M.C.; YAMANISHI, O.K.; PEIXOTO, J.R.; JUNQUEIRA, N.T.V.; SOUSA, M.A.F. Enxertia de progênies de maracujazeiro-roxo australiano em espécies nativas. Revista Brasileira de Fruticultura, v.31, n.3, p.823-830, 2009. DOI: http://dx.doi.org/10.1590/S010029452009000300028

R CORE TEAM. 2016. A language and environment for statistical computing. $\mathrm{R}$ Foundation for Statistical Computing, Vienna, Austria. Available at: $<$ http://www.rproject.org/>. Access on: May 10, 2018.

SANDERSON, K.J.; JAMESON, P.E. The cytokinins in a liquid seaweed extract: Could they be active ingredients? Acta Horticulturae, v.179, n.1, p.113-116, 1986. DOI: https://doi.org/10.17660/ActaHortic.1986.179.8

SANDERSON, K.J.; JAMESON, P.E.; ZABKIEWICZ, J.A. Auxin in a seaweed extract: Identification and quantitation of indole-3-acetic acid by gas chromatographymass spectrometry. Journal of plant physiology, v.129, n.3-4, p.363-367, 1987. DOI: https://doi.org/10.1016/ S0176-1617(87)80093-7

SANTOS, C.M.G.; CERQUEIRA, R.C.; FERNANDES, L.M.D.S.; RODRIGUES, J.D.; ONO, E.O. Substrates and boron on the rooting of red pitaya cuttings. Revista Ceres, v.57, n.6, p.795-802, 2010. DOI: http://dx.doi.org/10.1590/ S0034-737X2010000600015 
SANTOS, K.C.; KURTZ, S.M.T.F.; MÜLLER, S.D.; BIAVATTI, M.W.; OLIVEIRA, R.M. M.W.; SANTOS, C.A.M. Passiflora actinia hydroalcoholic extract and its major constituent, isovitexin, are neuroprotective against glutamate-induced cell damage in mice hippocampal slices. Journal of Pharmacy and Pharmacology, v.68, n.2, p.282-291, 2016. DOI: https://doi.org/10.1111/jphp.12512

SCHWAMBACH, J.; FADANELLI, C.; FETT-NETO, A.G. Mineral nutrition and adventitious rooting in microcuttings of Eucalyptus globulus. Tree Physiology, v.25, n.4, p.487-494, 2005. DOI: https://doi.org/10.1093/ treephys/25.4.487

SILVA, F.A.S.; AZEVEDO, C.A.V. The Assistat Software Version 7.7 and its use in the analysis of experimental data. African Journal of Agricultural Research, v.11, n.39, p.3733-3740, 2016. DOI: http://dx.doi.org/10.5897/ AJAR2016.11522
TAIZ, L.; ZEIGER, E. Fisiologia vegetal. 5.ed. Porto Alegre: Artmed, 2013. 918p.

ZANOLI, P.R.; AVALLONE, R.; BARALDI, M. Behavioral characterization of the flavonoids apigenin and chrysin. Fitoterapia, v.71, suppl.1., p.117-123, 2000. DOI: https://doi.org/10.1016/S0367-326X(00)00186-6

ZUFFELLATO-RIBAS， K.C.; RODRIGUES， J.D. Estaquia: uma abordagem dos principais aspectos fisiologicos. Curitiba: Editora UFPR, 2001. 39p.

ZUANAZZI, J.A.S.; MONTANHA, J.A. Flavonoides. In: SIMÕES, C.M.O.; SCHENKEL, E.P.; GOSMANN, G.; MELLO, J.C.P.; MENTZ, L.A.; PETROVICK, P.R. Farmacognosia: da planta ao medicamento. Florianópolis: Editora da UFSC, 2004. 577-612. 